\title{
Development and Interrogation of a Transcriptomic Resource for the Giant Triton Snail (Charonia tritonis)
}

\author{
AH Klein ${ }^{1,2} \cdot$ CA Motti $^{3} \cdot$ AK Hillberg $^{1,2} \cdot$ T Ventura $^{1,2} \cdot$ P Thomas-Hall $^{3} \cdot$ T Armstrong $^{3} \cdot$ T Barker $^{3} \cdot$ P Whatmore $^{2,4}$. \\ SF Cummins ${ }^{1,2} \mathbb{B}$
}

Received: 12 February 2021 / Accepted: 3 June 2021 / Published online: 30 June 2021

(c) The Author(s) 2021

\begin{abstract}
Gastropod molluscs are among the most abundant species that inhabit coral reef ecosystems. Many are specialist predators, along with the giant triton snail Charonia tritonis (Linnaeus, 1758) whose diet consists of Acanthaster planci (crown-ofthorns starfish), a corallivore known to consume enormous quantities of reef-building coral. C. tritonis are considered vulnerable due to overexploitation, and a decline in their populations is believed to have contributed to recurring A. planci population outbreaks. Aquaculture is considered one approach that could help restore natural populations of $C$. tritonis and mitigate coral loss; however, numerous questions remain unanswered regarding their life cycle, including the molecular factors that regulate their reproduction and development. In this study, we have established a reference $C$. tritonis transcriptome derived from developmental stages (embryo and veliger) and adult tissues. This was used to identify genes associated with cell signalling, such as neuropeptides and G protein-coupled receptors (GPCRs), involved in endocrine and olfactory signalling. A comparison of developmental stages showed that several neuropeptide precursors are exclusively expressed in post-hatch veligers and functional analysis found that FFamide stimulated a significant (20.3\%) increase in larval heart rate. GPCRs unique to veligers, and a diversity of rhodopsin-like GPCRs located within adult cephalic tentacles, all represent candidate olfactory receptors. In addition, the cytochrome P450 superfamily, which participates in the biosynthesis and degradation of steroid hormones and lipids, was also found to be expanded with at least 91 genes annotated, mostly in gill tissue. These findings further progress our understanding of $C$. tritonis with possible application in developing aquaculture methods.
\end{abstract}

Keywords Olfaction $\cdot$ Cytochrome P450 $\cdot \mathrm{G}$ protein-coupled receptor $\cdot$ Neuropeptide $\cdot$ Crown-of-thorns starfish

\section{Introduction}

The giant triton snail, Charonia tritonis (Family Ranellidae), is one of the largest gastropod snails, protected by a long, narrow shell that can measure up to half a meter in length (Hall et al. 2017a). They are found

SF Cummins

scummins@usc.edu.au

1 Genecology Research Centre, University of the Sunshine Coast, Maroochydore DC, QLD 4558, Australia

2 School of Science, Technology and Engineering, University of the Sunshine Coast, Maroochydore DC, QLD 4558, Australia

3 Australian Institute of Marine Science (AIMS), Cape Ferguson, Townsville, QLD 4810, Australia

4 eResearch Office, Queensland University of Technology, Brisbane, QLD 4000, Australia throughout the Indo-West Pacific region, primarily in tropical waters where the habitat consists of hard and sandy bottoms adjacent to shallow water reefs (Nateewathana and Aungtonya 1994). As one of the few active predators of adult crown-of-thorns starfish (Acanthaster planci; COTS), it is of significant ecological importance on coral reefs. Although an adult C. tritonis eats only 1.5 COTS per week on average (Endean 1969), its mere presence alters the behaviour of COTS (Hall et al. 2017a, b). This chemically mediated phenomenon has been referred to as "landscapes of fear" (Luttbeg and Kerby 2005; Preisser et al. 2005; Preisser and Bolnick 2008), whereby predator presence can induce changes in prey at the physiological, phenotypic and behavioural levels (Brown and Alexander 1994; Abrams 1995; Schmitz et al. 1997; Pinnegar et al. 2000; Bernot and Turner 2001; Dill et al. 2003; Witman et al. 2003; Bolnick and Preisser 2005; Toscano 
and Griffen 2014; Hall and Kingsford 2016; Morgan et al. 2016) and can strongly influence prey density (Luttbeg and Kerby 2005; Peckarsky et al. 2008a, b; Paterson et al. 2013). It has been postulated that the "zone of fear" produced by $C$. tritonis has the potential to prevent COTS aggregation, ultimately leading to decreased offspring due to altered reproductive capacity (Hall et al. 2017b).

As a result of overexploitation, $C$. tritonis is now considered rare across its tropical habitat. Unfortunately, a general lack of fundamental understanding of their biology has impacted our capacity to implement conservation through captive breeding and mitigate further damage caused by increasingly frequent COTS outbreaks. Basic information is known regarding $C$. tritonis mating behaviour and early life-stage development (embryonic/larval). For example, during mating, males mount the female shell, aligning their apertures to enable copulation, which can last up to $2 \mathrm{~h}$ (Zhang et al. 2013). It is thought that change in water temperature is a primary determinate for initiation of egg-laying (Thorson 1950), where a single female $C$. tritonis can lay between 2 to 50 egg capsules per day (over a 3 -month period), each capsule containing 2000 to 2750 fertilized eggs (Hall 2017, personal communication). Embryogenesis into the first veliger stage occurs within the egg capsule (up to 60 days post-fertilization), enhancing protection from predation. Post-hatch, planktonic larvae have been maintained for over 140 days (Nugranad et al. 2001; Zhang et al. 2013); however, there has been no report of larval settlement and metamorphosis. Although this process is well understood for many commercially important molluscs, i.e. GABA (gammaaminobutyric acid), diatoms or pregrazed conditioned plates are most commonly used to induce abalone larval settlement in hatcheries (Freeman 2001), the factor(s) required for the $C$. tritonis life cycle transition are still to be revealed.

Advances in 'omics' technologies devoted to gastropods (Klein et al. 2019) provide an approach to broadly investigate the molecular machinery that regulates physiology, including identifying genes involved in development and adaptation. In $C$. tritonis, an in silico neuropeptidome of the central nervous system (CNS) has provided an overview of all neuropeptide precursors (NPPs) present in adults, some of which are known to regulate growth and reproductive processes (Bose et al. 2017a). Transcriptomics also provides the means to explore the $C$. tritonis $\mathrm{G}$ protein-coupled receptor (GPCR) superfamily, which includes those that bind neuropeptides (NPs), as well as the various environmental chemical cues that are critical for predation and larval settlement (i.e. olfactory receptors). Regarding predation, a transcriptomic-proteomic analysis of the C. tritonis salivary gland has revealed putative venom and feedingrelated proteins, providing insight into the source of bioactive components used by the snails to prey on adult COTS (Bose et al. 2017a, b). The molecular basis by which $C$. tritonis can detoxify the COTS toxins (e.g. saponins) could be explained through analysis of cytochrome P450 (CYP450) enzymes. CYP450 enzymes are well known for their roles in the detoxification of foreign compounds (Hannemann et al. 2007; Isin and Guengeric 2007; Mansuy 1998).

This study aimed to provide a more comprehensive gene resource that could facilitate further targeted investigations into the mechanisms that promote and regulate $C$. tritonis life histories. We present the development and overview of this resource, as well as major findings into the identification of GPCRs, NPPs and the CYP450 superfamily.

\section{Materials and Methods}

\section{Broodstock and Animal Maintenance}

C. tritonis were collected within the Great Barrier Reef under permit (G13/36390.1 and G17/38293.1) at depths up to $30 \mathrm{~m}$ by Cairns Marine and Pacific Marine Group. Specimens were held in artificially aerated containers and transported to the Australian Institute of Marine Science (AIMS) aquarium facilities. At the time of collection, all individual specimens were measured by weight and length of shell. At AIMS, $C$. tritonis broodstock $(n=5)$ were maintained in a round 4000 -L flow-through tank with a flow rate of $5.45 \mathrm{~L} / \mathrm{min}$ (equivalent to 0.64 water exchanges/diurnally) of ambient filtered seawater (FSW; $1 \mu \mathrm{m}$, temperature ranging from $30^{\circ} \mathrm{C}$ in the summer to $23{ }^{\circ} \mathrm{C}$ during winter, salinity $32-35 \mathrm{ppt}$ ). Broodstock individuals were fed live adult COTS, which is the preferred diet for C. tritonis (Paterson and Poulsen 1988). Occasionally, alternative echinoderms such as Linckia laevigata and Strichopus chlorotus were offered.

Mating was observed in the summer months (DecemberFebruary) with egg-laying occurring from April to May (Hall et al. 2017a; Motti et al. 2018). Egg capsules containing prehatched individuals were left in the broodstock tank without human intervention. At 50 days post-fertilization (dpf), capsules were manually cut opened with a sterilised scalpel blade and veliger released into a sterile environment to avoid introduction of biological contamination, as well as to control hatching time. Newly hatched larvae were transferred to culture vessels; circulation was provided by introduction of $26^{\circ} \mathrm{C}$ $0.45 \mu \mathrm{m}$ filtered FSW from the base of the vessel and aeration via a tube positioned $\sim 10 \mathrm{~cm}$ below the water's surface. Moreover, all culture vessels were individually dosed with a microalgal mixture (Dunaliella sp., Isochrysis sp., Pavlova lutheri, Nannochloropsis oceania and Chaetoceros mulleri) at a concentration of 3000 cells $/ \mathrm{mL}$ using an automated feed pump (dosage varied from 4 to $0.4 \mathrm{ml} / \mathrm{min}$ depending on feed density required). For further details pertaining to larval rearing, refer to Motti et al. (2018). 
The health of post-hatched veligers was monitored daily using a stereomicroscope (Leica DFC 5500), and their activity, morphological development, and heart rate were recorded. To sort living veligers from dead, the neurotransmitter serotonin $(\sim 10 \mathrm{mM})$ - known to significantly increase locomotion in healthy veligers (Penniman et al. 2013) — was added (100-300 $\mu \mathrm{L} / \mathrm{L})$. Active swimming veligers were siphoned into a new culturing vessel, non-mobile individuals that had sunk to the bottom of the vessel were removed.

\section{RNA Isolation}

Encapsulated C. tritonis larvae at 25 and $50 \mathrm{dpf}(n \sim 1000$ each) were released from a single egg capsule using a sterilised scalpel blade, directly into RNAlater (Ambion). Freeswimming veligers at 14 -day post-hatch $(\mathrm{dph} ; n \sim 500)$ were collected via siphon over a $100 \mu \mathrm{m}$ filter and immediately transferred into RNAlater (Ambion). All samples were stored at $4{ }^{\circ} \mathrm{C}$. These developmental stages were selected as they provide ideal temporal and morphological separation. Foot, gill, posterior and anterior salivary gland, CNS, proboscis, tentacles, and mantle tissues of $C$. tritonis adults, previously collected and stored in RNAlater at $4{ }^{\circ} \mathrm{C}$ (Bose et al. 2017a, b), were used for RNA isolation. RNA isolation of $25 \mathrm{dpf}, 50 \mathrm{dpf}$, and $14 \mathrm{dph}$ veligers and adult tissues was performed with TRIzol reagent (Sigma-Aldrich, MO, USA), as per supplier's instructions. Total RNA was quality assessed through $1.6 \%$ agarose gel electrophoresis, and further quantified using a Nanodrop 2000 (Thermo Scientific, MA, USA) spectrometer at wavelengths 260 and $280 \mathrm{~nm}$ and thereafter stored at $-80{ }^{\circ} \mathrm{C}$ until further use. RNA integrity was analysed by Novogene (Hong Kong) or the Australian Genome Research Facility (AGRF; Australia) for library construction and sequenced (150 nucleotides paired-end reads) using an Illumina HiSeq 2500 sequencing platform. RNA samples having a RIN (RNA Integrity Number) value $>8$ were deemed of sufficient quality for sequencing.

\section{Transcriptome Assembly and Quantitation}

The 11 RNA-seq libraries ( 3 developmental, 8 adult tissue) contained approximately 525 million raw reads with a mean length of 91 base pairs (bp) combined ( $>40$ million reads per sample). Reads with adaptor contamination, or when uncertain nucleotides constitute more than $10 \%$ of either read $(N>10 \%)$, or when low-quality nucleotides (base quality less than 20) constitute more than $50 \%$ of the read, were discarded by Novogene data filtering. Quality of raw reads of each library were checked separately using FastQC (Brown et al. 2017), and trimmomatic used to delete the 14 nucleotides at the extremities of each read (Bolger et al. 2014). Trimmed reads of the 11 RNA-seq libraries were merged prior to assembly using Trinity (Grabherr et al. 2011), which applies a de novo reconstruction method. The guanine-cytosine content (GC-content) was calculated to represent the percentage of nitrogenous bases on an RNA molecule that are either $\mathrm{G}$ or $\mathrm{C}$ (from a possibility of four different bases, also including adenine and uracil in RNA). Quality of the assembly was assessed using the built-in Trinity Perl script to generate an N50 value. Alignment coverage rate was calculated using the program Bowtie (Langmead et al. 2009) with a cutoff set at 70\%. The level of completeness of our reference transcriptome was evaluated using bench-marking universal single-copy orthologs (BUSCO; v2.0) (Simão et al. 2015). Gene expression levels were calculated using RSEM software by applying the transcripts per million (TPM) method. The formula applied was $\operatorname{FPKM}(\mathrm{A})=(1,000,000 \times \mathrm{C}) /(\mathrm{N} \times \mathrm{L} \times 1000)$, where $\operatorname{FPKM}(\mathrm{A})$ is the expression of gene $\mathrm{A}$ as fragments per $\mathrm{kb}$ per million fragments, $\mathrm{C}$ is the number of fragments that uniquely aligned to gene $\mathrm{A}, \mathrm{N}$ is the total number of fragments that uniquely aligned to all genes, and $\mathrm{L}$ is the number of bases on gene A. Following assembly, Transdecoder was used to predict open reading frames (ORFs) with a selectable minimum default parameter of 100 amino acids ORF length (https://github.com/transDecoder/TransDecoder/wik). In addition to the reference transcriptome (i.e. all 11 libraries combined), reads from each sample were assembled independently as quality control for the reference transcriptome.

\section{Biological Annotation}

The BLASTp was performed against the NCBI non-redundant protein database for gastropods to obtain biological functional annotation relevant to $C$. tritonis. In order to increase the quality of the annotation, HMMER, a protein-family based annotation tool, was employed to search for all Pfam protein family profiles (Finn et al. 2013). Then, BLAST2GO pipeline was used to obtain the gene ontology (GO) annotation for each transcript (Conesa et al. 2005). Finally, transcripts were mapped to the KEGG database for annotation to predict their metabolic pathways. From each tissue, putative GPCRs were extracted using their Pfam accession number and prediction of transmembrane domain (TM) performed using TMHMM. Only GPCRs with a minimum of $5 \mathrm{TM}$ were retrieved for further analysis. GPCRs were classified into families using SeQuery tool (http://cluster.phy.ntnu.edu.tw/) (Hu et al. 2019). According to the classical A-F system, GPCRs can be grouped into 6 classes based on sequence homology and functional similarity (Attwood and Findlay 1994; Kolakowski 1994; Davenport et al. 2013): class A (or 1) (rhodopsin-like), class B (or 2) (secretin receptor family), class C (or 3) (metabotropic glutamate/pheromone), class D (or 4) (fungal mating pheromone receptors), class $\mathrm{E}$ (or 5) (cyclic AMP receptors) and class F (or 6) (frizzled/smoothened). 
To investigate candidate olfactory receptors (ORs), a list of ORs from Aplysia californica (Cummins et al. 2009) were blasted against proteins from the newly assembled reference transcriptome of $C$. tritonis with an e-value cutoff set at $1 \mathrm{e}-5$. ORs found in the tentacles of both species were used to build a phylogenetic tree (MEGA7). NPPs derived from the molluscs Lottia gigantea (Veenstra 2010), Pinctata fucata, Crassostera gigas (Stewart et al. 2014) and Theba pisana (Adamson et al. 2015), as well as from a previous study of $C$. tritonis (Bose et al. 2017a), were used in a BLASTp search (e-value cutoff set at $1 \mathrm{e}-5$ ) to identify homolog proteins from our $C$. tritonis samples. Matches were manually assessed against known NPs to determine conservation of putative bioactive regions.

The reference transcriptome of $C$. tritonis was searched using the hidden Markov model (HMMER v3.3) (Finn et al. 2011) and putative CYP450 proteins identified using the global PFAM model for (CYP450) accession (PF00067; only full-length sequences and partial-length sequences above 250 amino acids were considered) (http://pfam.sanger. ac.uk/). Putative CYP450s were named based on the homology with CYP450 from the Cytochrome P450 Homepage eukaryote databank (Nelson 2009). Values of $40 \%$ and 55\% amino acid identity were used to assign CYP450s to families and subfamilies, respectively. These $C$. tritonis CYP450s families were further divided into clans similar to those in vertebrates. The CYP450 families were then identified using BLASTp. If identity was above $30 \%$, and typical conserved CYP450 motifs important for catalytic activities (Rewitz et al. 2006), including heme-binding region, PERF motif, $\mathrm{K}$-helix region, I-helix region and C-helix, were present, then a similar function was assigned based on categories used for humans (Mittal et al. 2015). The deduced amino acid sequences of C. tritonis CYP450s were subjected to Multiple Expectation Maximization for Motif Elicitation (MEME, http://meme-suite.org/) (Bailey et al. 2009) analysis for identification of conserved motifs. The consensus sequences of the heme-binding region, also known as 'P450 signature', is 'PFXXGXRXCXG', and for the PERF motif 'PXXFXPE/ DRF'. The consensus sequences for K-helix, I-helix and C-helix regions are 'EXXR', 'GXE/DTT' and 'WXXXR', respectively. Sequences of the 5 conserved CYP450 motifs were extracted and then subjected to WEBLOGO (http:// weblogo.berkeley.edu/) (Crooks et al. 2004) to create the sequence logos.

\section{Veliger Heart Rate Assay}

Identified NPs were assessed for their ability to regulate $C$. tritonis veliger heart rate (beats per minute; bpm). FMRFamide, FFamide and egg-laying hormone (ELH) were synthesized by ChinaPeptides Co. Ltd. Veligers $(n=10)$ were added to each well of a 6-well plate containing $10 \mathrm{~mL}$
FSW. Veliger heart rate was observed under a microscope for 3 min prior to addition of treatments $(10 \mu \mathrm{M})$. Serotonin (known to accelerate ciliary beating rate) was used as a positive control, while FSW was used as a negative control. Significance was estimated based on adjusted $P$ value using the Bonferroni correction with a threshold set at $P<0.05$. Standard deviation and $P$ value was calculated using R (version 1.2.5033).

\section{Results and Discussion}

\section{Assembly and Annotation of the Charonia tritonis Reference Transcriptome}

In molluscs, reference transcriptome databases have proven useful for providing insights into the molecular machinery that governs early life-stage development and adult physiological processes. For example, developmental transcriptomes of the gastropods Rapana venosa (whelk) and Aplysia californica (sea slug) have enabled identification of genes associated with transitions between life stages (Song et al. 2016; Heyland et al. 2011), and as more datasets become available, comparative analysis can establish evolutionarily connectedness (De Oliveira et al. 2016). Here, a reference transcriptome for $C$. tritonis including combined early life stages ( $25 \mathrm{dpf}, 50 \mathrm{dpf}$, and $14 \mathrm{dph}$ ) and various adult tissues, and also separate assemblies per sample, were established to facilitate the subsequent targeted interrogation of genes (Supplementary File S1).

In $C$. tritonis, the temporal and anatomical changes associated with embryogenesis and early larval development have been described (Berg 1971; Nugranad et al. 2001; Zhang et al. 2013). Embryogenesis up to a late larval (protoconch I) stage occurs within the egg capsule (Fig. 1A) and has been reported to be in the order of 35 to over $60 \mathrm{dpf}$ (Zhang et al. 2013). At around $25 \mathrm{dpf}$, we observed the protoconch shell and the beginning of eyespot formation (Fig. 1B). By approximately $50 \mathrm{dpf}$, the protoconch shell, operculum, foot and right tentacle were readily distinguishable (Fig. 1C), then at $14 \mathrm{dph}$, hatched free-swimming veligers were observed with one pair of velar lobes (Fig. 1D).

Paired-end sequencing of RNA samples from developmental and adult $C$. tritonis tissues generated $120-\mathrm{Gb}$ raw data in FastQ format (GenBank accession number PRJNA699909). Subsequent de novo assembly generated a total of 613,506 contigs, including isoforms, and 61,611 proteins. To facilitate discovery analysis, small proteins having a minimum length of 100 amino acids were included, giving a final N50 value of $556 \mathrm{bp}$, L50 (corresponding number of sequences) of 126,520 and N90 of 235 for this reference transcriptome. This is similar 
Fig. 1 Photos showing Charonia tritonis life stage. A Brooding female guarding recently laid intensely orange-coloured egg capsules. B A single yellow/opaque encapsulated larvae at $25 \mathrm{dpf}$. C A single encapsulated protoconch I larvae at 50 dpf. D A free-swimming veliger at $14 \mathrm{dph}$
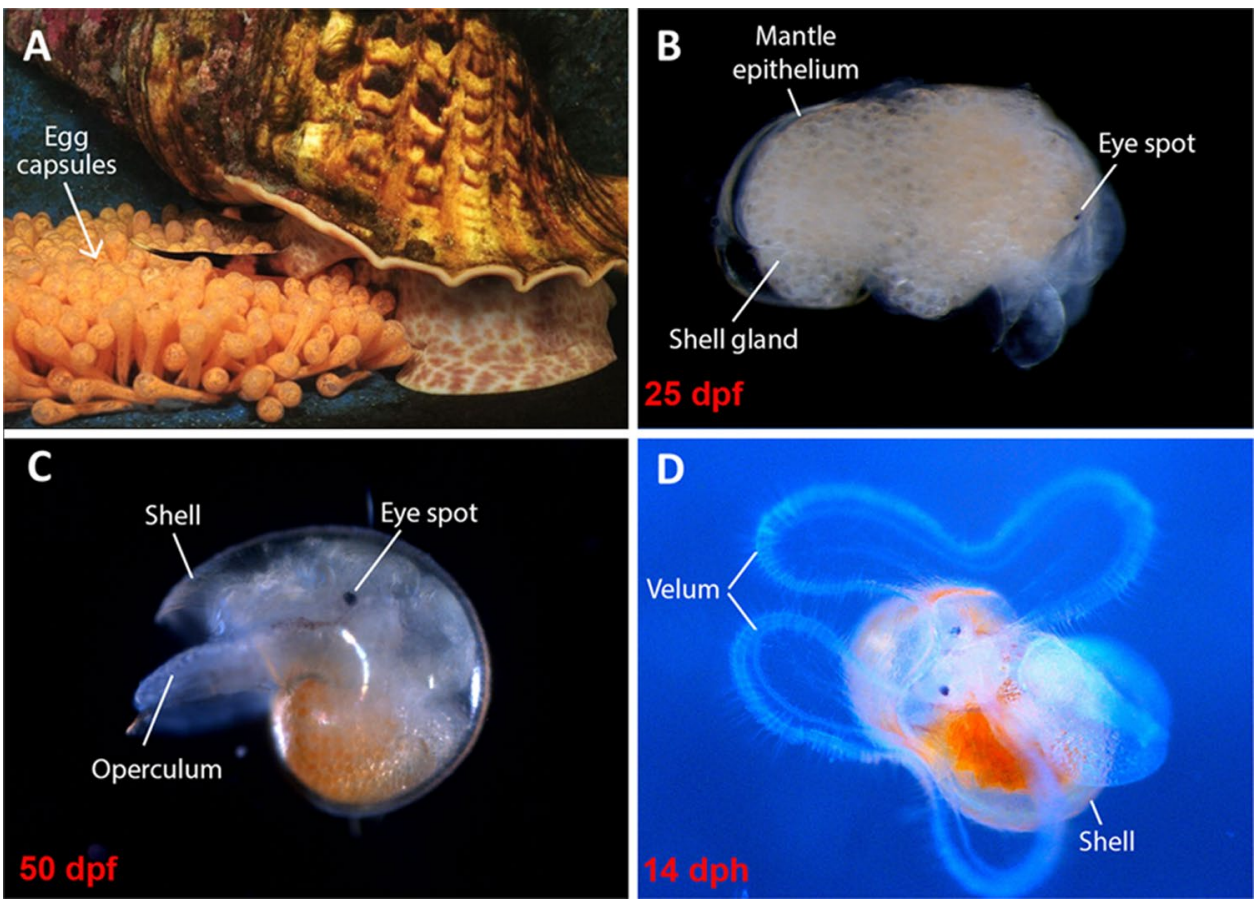

to that reported from the neural transcriptome of $C$. tritonis, with N50 of 641 bp (Bose et al. 2017a). The Bowtie coverage rate of $81 \%$ lends confidence to the assembly quality. To further evaluate the completeness of the reference transcriptomes (combined and individual), proportions of complete as well as partial homologs of 429 conserved eukaryote genes were assessed. The reference transcriptomes contained $83 \%$ of the complete conserved eukaryote genes, and $6.5 \%$ of fragmented BUSCO genes that is comparable to other mollusc transcriptomes published recently (Ip et al. 2018, 2016; Sun et al. 2012; Mu et al. 2017; Bankers et al. 2017; De Oliveira et al. 2016; Gerdol et al. 2017). To guarantee the best annotation possible, a combination of tools using different bioinformatics databases was applied. BLAST, using the non-redundant database and GO, annotated 14,095 and 11,575 proteins, respectively, with an e-value threshold set at $1 \mathrm{e}-5$. A relatively high number of these proteins annotated to biological processes associated with signal transduction, GPCR signalling, cell communication and neurotransmitter transport (Fig. 2). This was supported by a relative abundance of proteins corresponding to the molecular function groups

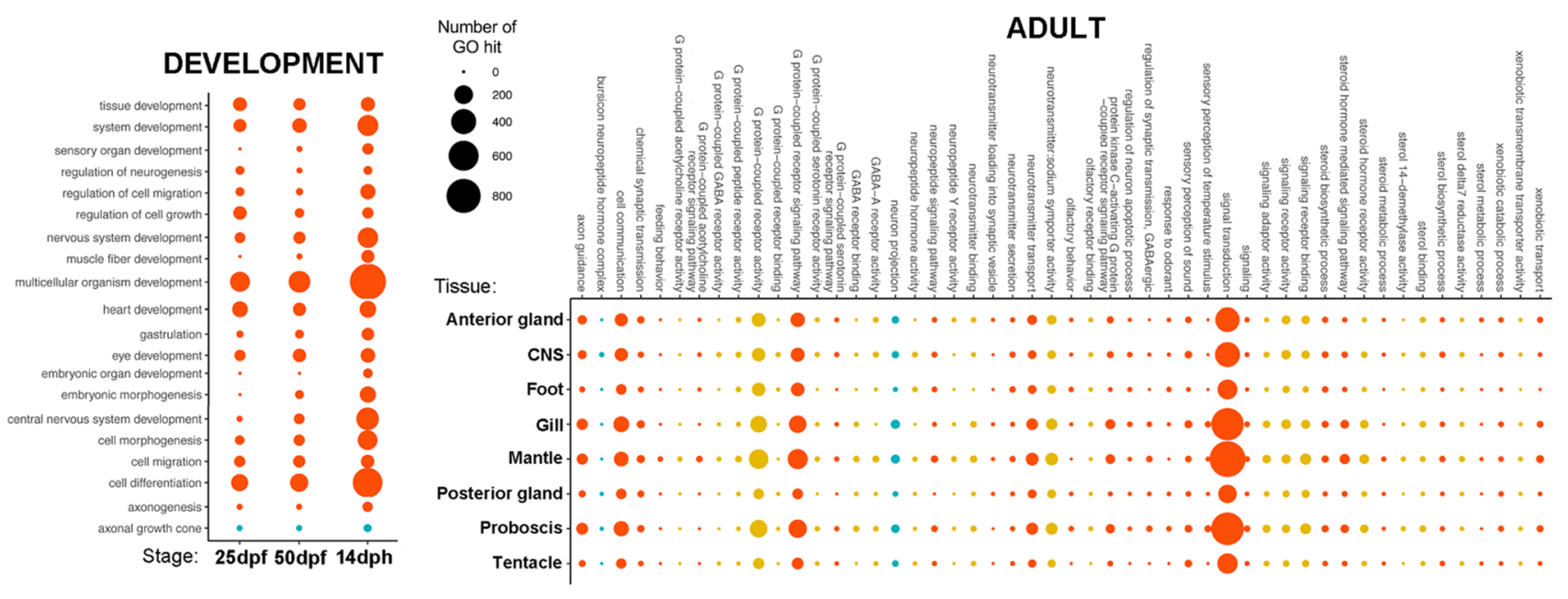

Fig. 2 Charonia tritonis gene ontology (GO) annotation for developmental and adult tissues. dpf, days post-fertilisation; dph, days post-hatch; blue, cell compartment; yellow, molecular function; red, biological process 
for signalling receptor binding, GPCR activity and NP hormone activity.

\section{Identification of GPCR Genes, Including Candidate Olfactory Receptors}

GPCRs are 7 TM proteins that constitute a vast family capable of binding ligands and regulating a wide range of functions, including autocrine, paracrine and endocrine processes. They are also associated with larval/veliger growth and metamorphosis (Bai et al. 2011; Yang et al. 2014). Four classes of GPCRs were identified and categorised in C. tritonis, namely the rhodopsin-like, secretin and metabotropic glutamate/pheromone GPCRs (Supplementary File S2). GPCRs identified as 'outliers' by SeqQuery were, in fact, NP-like GPCRs, and those identified as 'not GPCR' were too distant from those present in the SeqQuery databank (primarily constituting mammalian GPCRs). In the three development stages, targeted analysis revealed that, overall, more GPCRs are expressed at $50 \mathrm{dpf}$ and belong to the rhodopsin-like GPCR family (Fig. 3A). At 14 dph, the glutamate GPCRs were more prominent.

Comparing larval/veliger and adult GPCRs raises interesting questions about their functional capabilities, inclusive of those that may regulate settlement and metamorphosis. Eight GPCRs found in the developmental stages were absent from adult tissues (Supplementary File S2). Of these, one is exclusive to $14 \mathrm{dph}$ veligers and annotates to a GPCR that is conserved throughout the animal kingdom, named transmembrane protein 145 . It is predicted to be involved in a GPCR signalling pathway in response to a pheromone stimulus (GO:0,019,236). Homologs to C. tritonis transmembrane 145 GPCR-like protein are found in other molluscs such as Pomacea caniculata and Aplysia californica, and even in mammals, where the Mus musculus homolog shows most similarity within the extracellular $\mathrm{N}$-terminal region and 7 TM domains (Fig. 3B). Also of interest is a metabotropic glutamate GPCR-like protein (TRINITY_DN99081_c0_g1_ i1) that was exclusive to $14 \mathrm{dph}$ and the adult cephalic tentacle, suggesting a role in olfaction. Based on its e-value and query coverage from blast, this GPCR is largely restricted to molluscs. Metabotropic glutamate GPCRs are known to bind glutamate through a large extracellular $\mathrm{N}$-terminus region and modulate neural synaptic transmission (Cochilla and Alford 1998; Cartmell and Schoepp 2000).

Similar to other predatory gastropods, Charonia spp. are likely to use olfaction to locate prey, made possible by a pair of large sensory cephalic tentacles that facilitate directional odour detection (Hall et al. 2017a). Of the 143 GPCRs identified, 137 were identified in $C$. tritonis adult tissues, with the majority identified from the cephalic tentacles (Fig. 3C). Sixty-six GPCRs (48\%) were present in the cephalic tentacle, including 61 exclusive to the cephalic tentacle. Most GPCRs identified were classified as rhodopsin-like. Rhodopsin-like GPCRs are well known for their role as chemosensory receptors, and have been implicated in olfactory processing in aquatic gastropod molluses such as $A$. californica (Cummins et al. 2009) and Biomphalaria glabrata (Adema et al. 2017). Candidate ORs previously identified in the gastropod A. californica (Cummins et al. 2009) were utilised in a comparative phylogenetic analysis with $C$. tritonis cephalic tentacle GPCRs (Fig. 4). Fifty-three candidate ORs, clustering into four distinct clades, were identified for $C$. tritonis.

\section{Identification of Neuropeptide Precursor Genes and Functional Peptide Analysis in Veligers}

NPs are widely recognised in molluscs for their roles as neurotransmitters and neuromodulators (Cahill and Koury 2016), with many regulating key processes like feeding, reproduction and osmoregulation (Morishita 2017). Also, the processes of larval settlement and metamorphosis in marine molluscs are largely controlled by sensory recognition leading to activation of endogenous signalling (Scheltema and RS 1974; Hadfield 1984; Cahill and Koury 2016; Geraerts et al. 1991). For example, in A. californica, NP enrichment during the metamorphic stage has been observed (Heyland et al. 2011). Our in silico NP analysis of the $C$. tritonis reference transcriptome identified a total of 117 NPP transcripts (including isoforms), coding for 37 different NPP genes conserved with other molluscs, some of which appear to be developmental stage- or tissuespecific (Supplementary File S2).

During development (both pre- and post-hatch), 35 NPP genes were identified, including 16 that were present at all three life-stages (Fig. 5A). Temporal change in expression of NPP genes was observed as development proceeded; 20 NPP genes were identified at $25 \mathrm{dpf}$, then increasing to 29 at 50 dpf (including achatin, buccalin, ELH, enterin, FMRFamide, LFRFamide, PKYMDT, PRQVFamide and PXVFamide). At $14 \mathrm{dph}$, a further six NPP genes were expressed, including the CCK/SK, elevenin, FFamide, GGNG, LASGLVamide and pedal, while ELH, pleurin and NPF/NPY were absent. The number of isoforms was investigated for each NPP gene and within each developmental stage (Fig. 5A). The highest number of isoforms was found for the feeding circuit-activating peptide (FCAP), FMRFamide, enterin, myomodulin and buccalin, particularly at $14 \mathrm{dph}$. Buccalin and myomodulin have been associated with the intrinsic modulation of accessory radula closer activity (associated with biting) in A. californica (Cropper et al. 1988), which may correlate with the requirement for $C$. tritonis larvae feeding (Kellett et al. 1996). The $C$. tritonis ELH gene was only found in $50 \mathrm{dpf}$ larvae and adult CNS tissue. ELH is most often associated with the stimulation of egg laying or spawning in adult gastropods (Stewart 

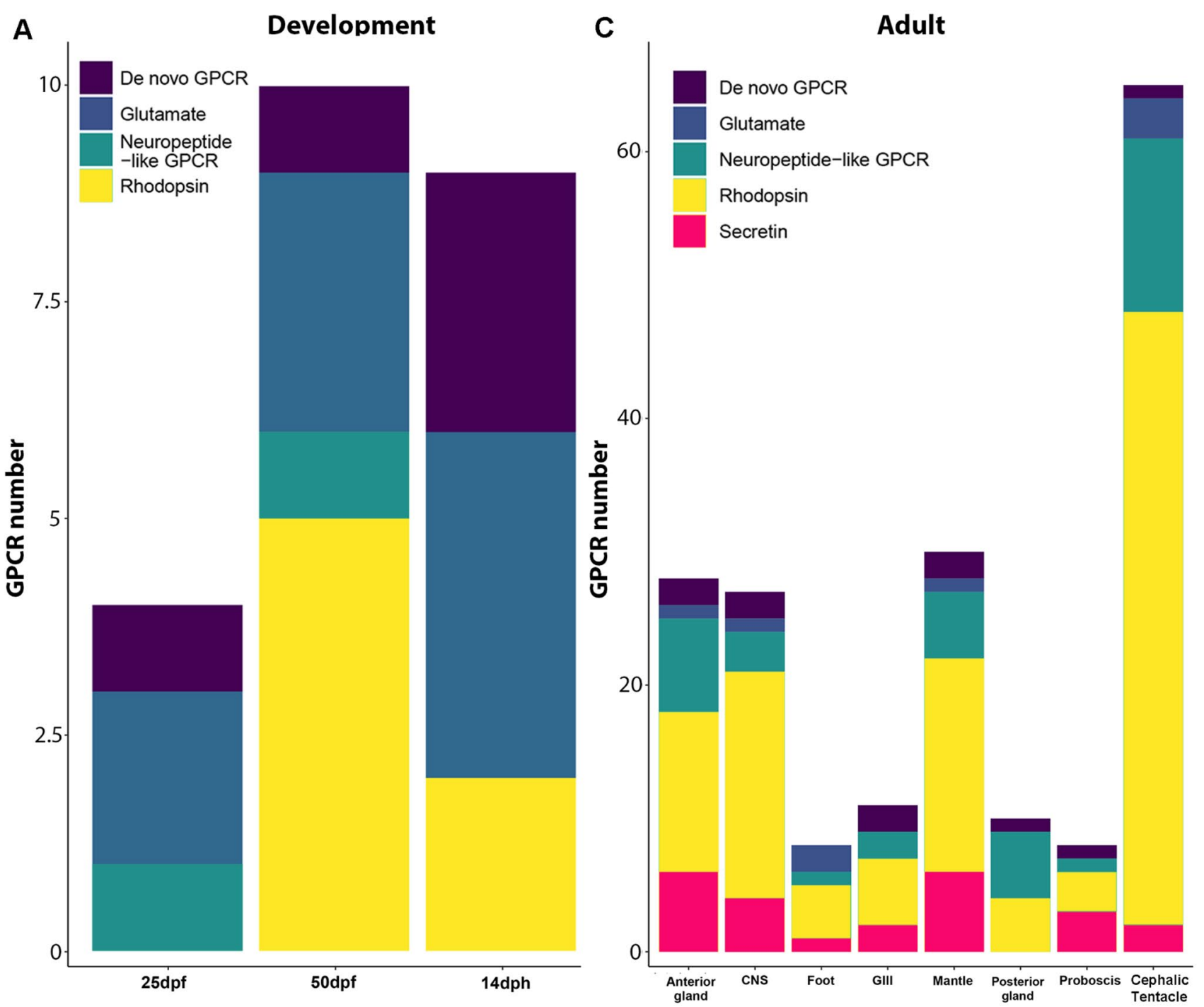

\section{B}

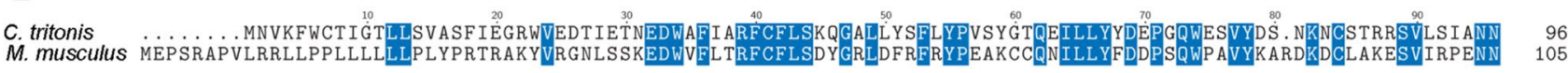

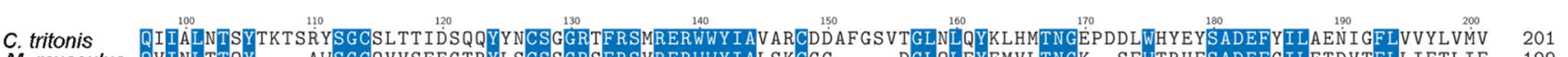

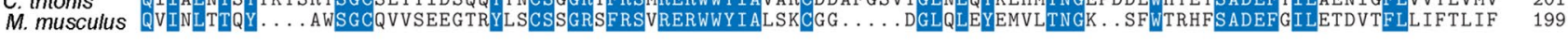

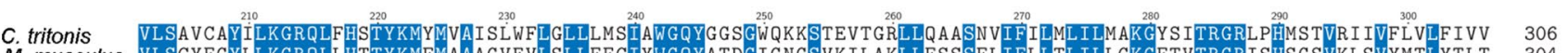
M. musculus VLSCYFGYLLKGRQLLHTTYKMFWAAAGVEVLSLLFFCIYWGQYATDIGNGSVK ILAKLLF SSSFLIFLLTLILLGEGFTVIRGRISHSGSVKLVYMTLYTLT 304

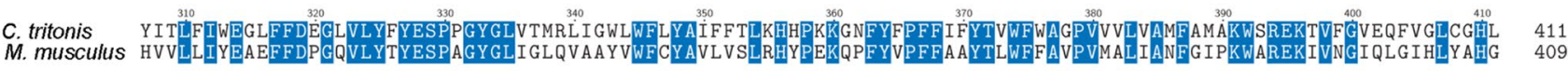

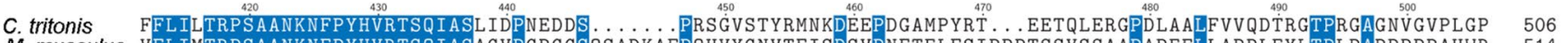
M. musculus VELIMTRPSAANKNFPYHVRTSQIASA GVPGPG GQSADKAFPQHVYGNVTF ISDSVPNFTELFS IPPPTSSVSSAAPAPEELLAPPLEYLIPLPAPPPPPAHWR 514

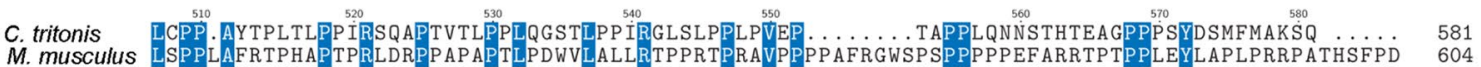

Fig. 3 Classification of G protein-coupled receptors (GPCRs) identified in Charonia tritonis into different families: glutamate, secretin, rhodopsin, cAMP neuropeptide-like and de novo. A GPCRs present at different stages of early life development: 25 days post-fertilisation (dpf), $50 \mathrm{dpf}$ and 14 days post-hatch (dph). B Multiple sequence alignment of a GPCR exclusive to veligers at $14 \mathrm{dph}$ (TRINITY DN337635_c4_g1_i1) with a Mus musculus homolog GPCR. Blue shading represents conservation. C GPCRs present within different adult tissues. See Supplementary File S3 for all C. tritonis GPCR sequences 


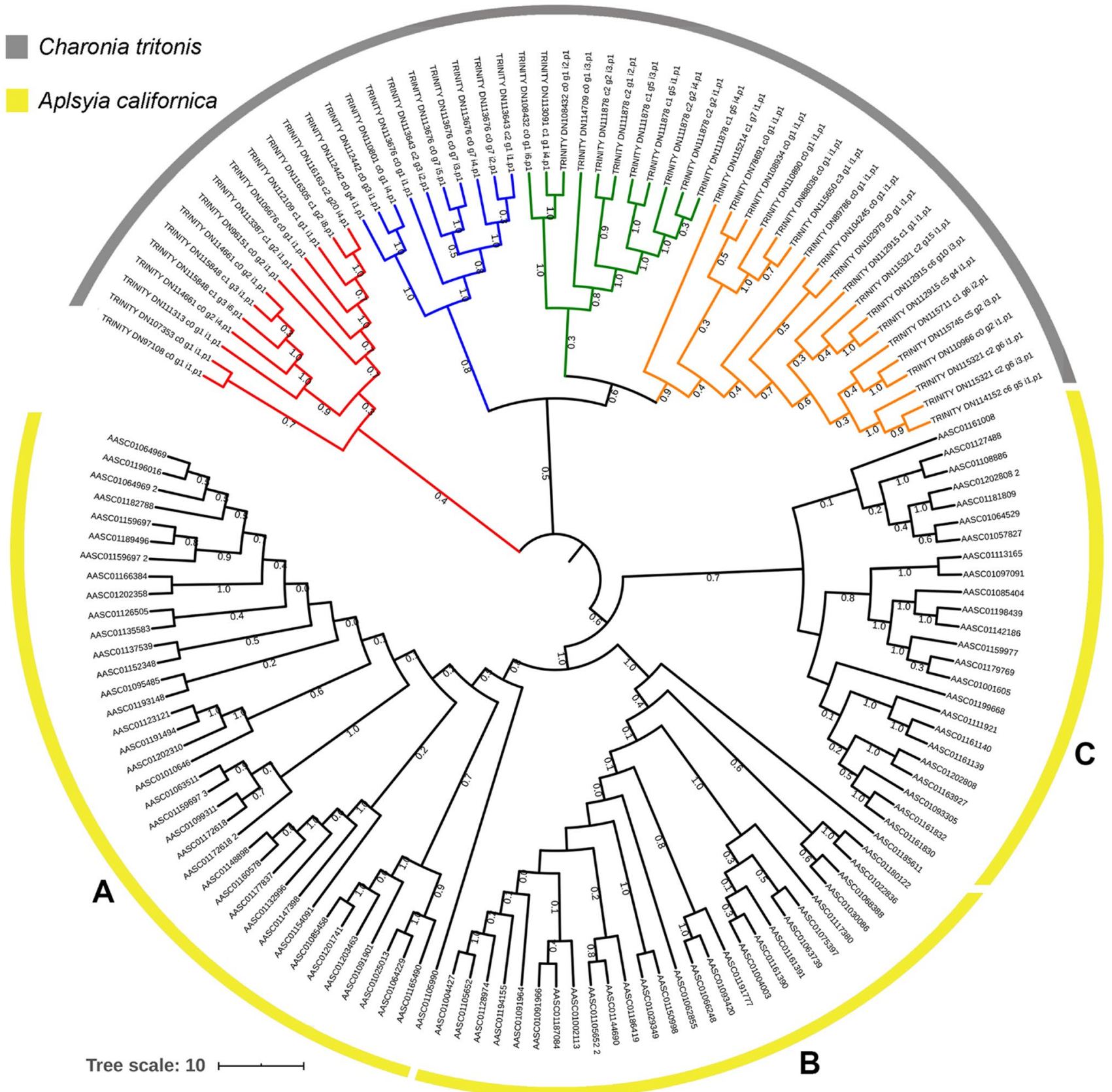

Fig. 4 Phylogenetic analysis of candidate olfactory receptors (ORs) identified in the cephalic tentacle of Charonia tritonis. Phylogenetic tree demonstrates the clustering of $C$. tritonis candidate ORs, repre-

et al. 2016; Cummins et al. 2010), as yet no function has been inferred for larvae or veligers.

In adult $C$. tritonis, all NPP genes besides NPF/NPY were found in the CNS, which also had the highest levels of gene expression (Supplementary File S2). Notably, the NPF/NPY gene was observed in $C$. tritonis larvae at both $25 \mathrm{dpf}$ and $50 \mathrm{dpf}$, but not at $14 \mathrm{dph}$. NPF regulates swimming depth of larvae in the annelid Platynereis dumerilii (Conzelmann et al. 2011). Besides the CNS, the cephalic tentacle and sented by red, blue, green and orange clades. Aplysia californica candidate $\mathrm{ORs}$ are grouped into $\mathbf{A}, \mathbf{B}$ and $\mathbf{C}$

mantle tissues contained a high proportion of NPP genes (17 and 18, respectively), which is likely due to their relative abundance of neural innovation. In the adult tissues analysed, FCAP, enterin, LFRFamide and myomodulin NPP genes were most broadly expressed across all tissues (Fig. 5B). Others were more spatially refined, such as APGWamide. APGWamide has been well studied in molluscs, demonstrating a key role in male copulation behaviour, for example, in the basommatophoran pulmonate freshwater snail Lymnaea 


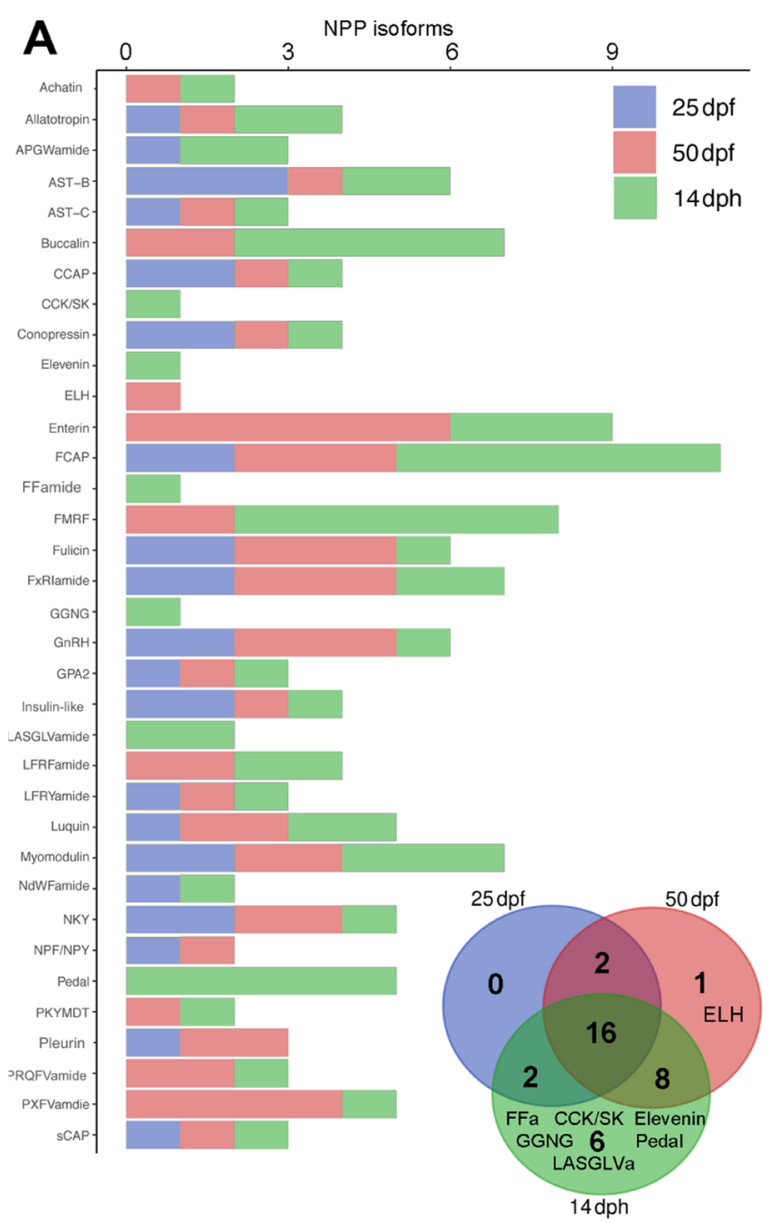

B

\begin{tabular}{|c|c|c|c|c|c|c|c|c|}
\hline & Foot & CNS & Gill & Mantle & Proboscis & \begin{tabular}{|c|} 
Cephalic \\
Tentacle
\end{tabular} & \begin{tabular}{|c|}
$\begin{array}{c}\text { Anterior } \\
\text { gland }\end{array}$ \\
\end{tabular} & $\begin{array}{c}\text { Posterior } \\
\text { gland }\end{array}$ \\
\hline \multicolumn{9}{|l|}{\begin{tabular}{|l|} 
Achatin \\
\end{tabular}} \\
\hline \multicolumn{9}{|l|}{ Allatotropin } \\
\hline \multicolumn{9}{|l|}{ APGWamide } \\
\hline \\
\hline & & & & & & & & \\
\hline \multicolumn{9}{|l|}{ Buccalin } \\
\hline \multicolumn{9}{|l|}{ Bursicon } \\
\hline \multicolumn{9}{|l|}{ CCAP } \\
\hline \multirow{2}{*}{\multicolumn{9}{|c|}{\begin{tabular}{|l} 
CCK/SK \\
Conopressin \\
\end{tabular}}} \\
\hline & & & & & & & & \\
\hline \multicolumn{9}{|l|}{ Elevenin } \\
\hline \multicolumn{9}{|l|}{ ELH } \\
\hline \multirow{2}{*}{\multicolumn{9}{|c|}{$\begin{array}{l}\text { Enterin } \\
\text { FCAP }\end{array}$}} \\
\hline & & & & & & & & \\
\hline \multicolumn{9}{|l|}{ FFamide } \\
\hline \multicolumn{9}{|l|}{ FMRFamide } \\
\hline \multirow{2}{*}{\multicolumn{9}{|c|}{ Fulicin }} \\
\hline \multirow{2}{*}{\multicolumn{9}{|c|}{$\begin{array}{l}\text { FxRlamide } \\
\text { GGNG }\end{array}$}} \\
\hline & & & & & & & & \\
\hline \multicolumn{9}{|l|}{ GnRH1 } \\
\hline \multicolumn{9}{|l|}{ GPA2 } \\
\hline \multirow{2}{*}{\multicolumn{9}{|c|}{$\begin{array}{l}\text { GPB5 } \\
\text { Insulin-like peptides }\end{array}$}} \\
\hline & & & & & & & & \\
\hline \multicolumn{9}{|l|}{ LASGLVamide } \\
\hline \multirow{2}{*}{\multicolumn{9}{|c|}{ LFRFamide }} \\
\hline \multirow{2}{*}{\multicolumn{8}{|c|}{ LFRYamide }} & \\
\hline \multicolumn{6}{|l|}{ Luquin } & & & \\
\hline \multirow{2}{*}{\multicolumn{9}{|c|}{$\frac{\text { Myomodulin }}{\text { NdWFamide }}$}} \\
\hline & & & & & & & & \\
\hline \multicolumn{9}{|l|}{ NKYamide1/2 } \\
\hline \multicolumn{9}{|l|}{$\mathrm{NPF} / \mathrm{NPY}$} \\
\hline \multicolumn{9}{|l|}{ Pedal } \\
\hline PKYMDT & & & & & & & & \\
\hline Pleurin & & & & & & & & \\
\hline PRQFVamide-like & & & & & & & & \\
\hline PXFVamide & & & & & & & & \\
\hline sCAP/Pyro & & & & & & & & \\
\hline
\end{tabular}

Fig. 5 Summary of neuropeptide precursor (NPP) genes present in Charonia tritonis. A Graph showing NPP isoforms identified in early life development stages: 25 day post-fertilisation (dpf), $50 \mathrm{dpf}$ and

stagnalis (Croll and Van Minnen 1992; Croll et al. 1991; Van Golen et al. 1995; Van Kesteren et al. 1995; York et al. 2012). It has also been detected in the CNS of other snails, such as Fusinus ferrugineus (Kuroki et al. 1990), the African giant snail Achatina fulica (Liu et al. 1991) and Cornu aspersum (Liu et al. 1991, 1993; Chen and Walker 1992; Liu and Takeuchi 1993, 1995). FxRIamide, GGNG and insulin-like peptide genes were found at relatively high levels in the mantle, while the foot contained a notable level of myomodulin. In molluscs, the insulin-like peptide has been studies in different oysters (Crasstostera gigas and Pinctada fucata martensii) where it has been associated with a role in controlling development, growth, reproduction (Moon and Choi 2020) and involved in cell activity, glycogen metabolism and other physiological processes (Zhang and He 2020; Antonova et al. 2012). Pedal peptides are known to be involved in the control of locomotion and ciliated activity in molluscs (Hall and Lloyd 1990). In C. tritonis, with the exception of adult CNS, pedal peptides are only found at $14 \mathrm{dpf}$, the latest stage of early life development examined in this study. A
14 day post-hatch (dph). B Summary of NPP genes present in adult tissues. Blue shading represents identified. See Supplementary File S3 for all Charonia tritonis NPP sequences

similar expression pattern has been reported in A. californica (Heyland et al. 2011), for which pedal peptides are highly expressed in larval and metamorphic stages.

The identification of NPP genes and their distribution provides opportunities for functional analysis in $C$. tritonis. First, the neurotransmitter serotonin $(10 \mu \mathrm{M})$ was tested; it can elicit increased larval activity through stimulating ciliary beating in the sea snails Ilyanassa obsoleta and Crepidula fornicate (Penniman et al. 2013; Braubach et al. 2006) and induce metamorphosis in competent $I$. obsoleta larvae (Couper and Leise 1996). In this study, it has been successfully used to separate live swimming $C$. tritonis veliger from dead in culture (see 'Materials and Methods'). Furthermore, it was found to stimulate an increased heart rate beat frequency (av. 45 bpm), although not significantly (Fig. 6).

NPs derived from the FFamide, FMRFamide and ELH NPPs were tested in a veliger heart rate assay (Fig. 6). The FFamide NPP gene was only present in 14 dph veligers. Little is known regarding the function of FFamide in molluscs, however, neuropeptidomics of various species has proven its 


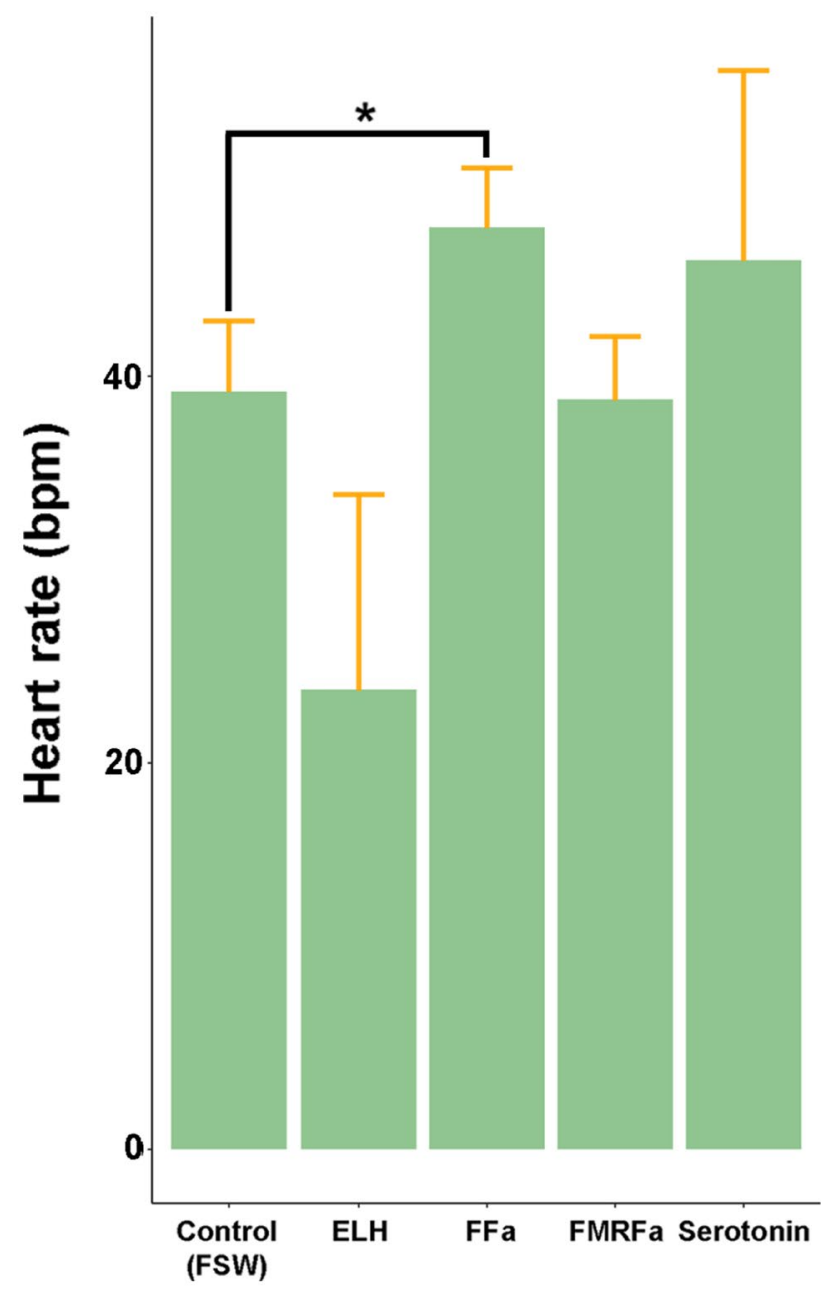

Fig. 6 Response of Charonia tritonis veliger heart rate (beats per minute; bpm) to chemical stimuli. Neuropeptides and serotonin were administered at $10 \mu \mathrm{M}(n=10)$. FSW, filtered seawater. *Significance is $p<0.05$

high conservation throughout molluscs (Stewart et al. 2014; Bose et al. 2017a; Zhao et al. 2016), suggesting an evolutionarily conserved and critical function. To date, it is known to play a role in the modulation of muscle contraction in male copulatory organs (Li et al. 1995) and increases in expression in the freshwater clam (Corbicula fluminea) upon exposure to organophosphate chemicals (Wang et al. 2018). Here, synthetic GINPNMNSLFFamide $(10 \mu \mathrm{M})$ stimulated a significant increase in $C$. tritonis veliger heart rate. The FMRFamide has been more widely associated with the stimulation of heart rate, where for example, it can increase both the force and frequency of beating in Lymnaea (Buckett et al. 1990) and the crab Callinectes sapidus (Price and Greenberg 1977). FMRFamide is also known to modulate ciliary beat frequencies in I. obsoleta and C. fornicata larvae (Penniman et al. 2013), and its expression was detected in pre-hatched $A$. californica and L. stagnalis, suggesting a patterning function of the nervous system in these species (Dickinson and Croll 2001; Dickinson et al. 2000). Its presence (and relatively high number isoforms) in $14 \mathrm{dph}$ C. tritonis supported a similar role. However, application of FMRFamide did not stimulate any observable change in C. tritonis veliger heart rate.

ELH (DISLNQDLKSLANMLLAREYDRILSNRMNREFLRKIGamide) caused a decrease (not significant) in veliger heart rate. Although ELH was only detected in 50 $\mathrm{dpf}$ veligers, its presence during development does suggest it is not strictly a reproduction-related NP. In support of this, ELH does have homology with a deuterostome stress response hormone (corticotropin-releasing factor), as well as arthropod diuretic hormone 44 (DH44) (Mirabeau and Joly 2013; Conzelmann et al. 2013), which does not stimulate reproductive behaviours.

\section{Identification of Cytochrome P450 genes}

C. tritonis are one of the few active predators of adult COTS (De Lange et al. 1997), due in large part to their capacity to detoxify saponins, a family of defensive chemicals present within starfish and other echinoderms (Kamyab et al. 2019). The CYP450 enzyme system of molluscs (and other phyla) are widely involved in molecule biosynthesis and biotransformation of xenobiotics and are also key to many developmental processes (Jia et al. 2002; Rewitz et al. 2006). This enzyme family also contains excellent candidates hypothesised to be involved in the catabolism of saponins, as well as mechanisms for settlement and metamorphosis.

In this study, we identified 91 putative CYP450 genes in $C$. tritonis (Supplementary File S2), all encoding proteins with motifs consistent with CYP450 proteins, such as the hemebinding region and PERF motif (Fig. 7A), thereby validating our CYP450 detection approach. By comparison, the genome of $P$. caniculata revealed 157 CYP450 genes (Liu et al. 2018) that are mostly expressed in the hepatopancreas, gill and kidney. Furthermore, a genomic investigation of $B$. glabrata found 99 CYP450 genes, including those with adult tissue-specific expression; developmental stages were not investigated (Adema et al. 2017). We found that 59 C. tritonis CYP450 genes were expressed during the three development stages, with the largest number associated with steroid hormone biosynthesis (Fig. 7B). The existence of steroid hormones in molluscs is far from clear (Fernandes et al. 2011); therefore, the potential function of steroid hormone metabolism associated with CYP450 genes in $C$. tritonis requires further investigation. In post-hatch $C$. tritonis veligers, three families of CYP450 genes were identified that annotate to roles in arachidonic acid processing, bile acid biosynthesis and fatty acid omega oxidation, all of which would be considered normal larval metabolic processes. Furthermore, the number of CYP450 annotated to xenobiotic metabolic processing drastically increases post-hatch, correlating with exposure to increased environmental stimuli. 
A
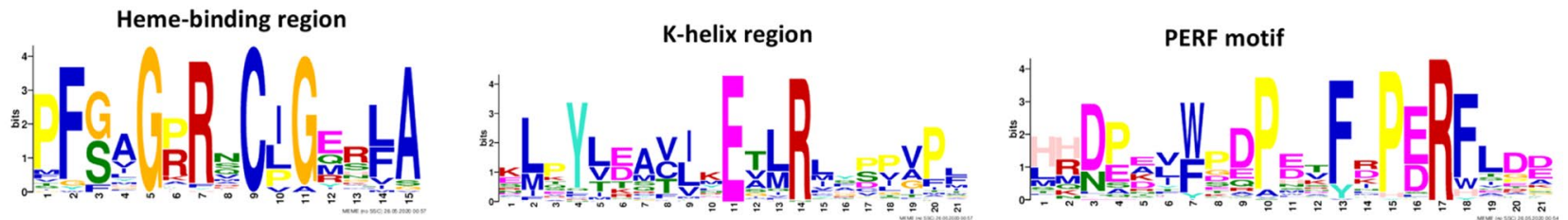
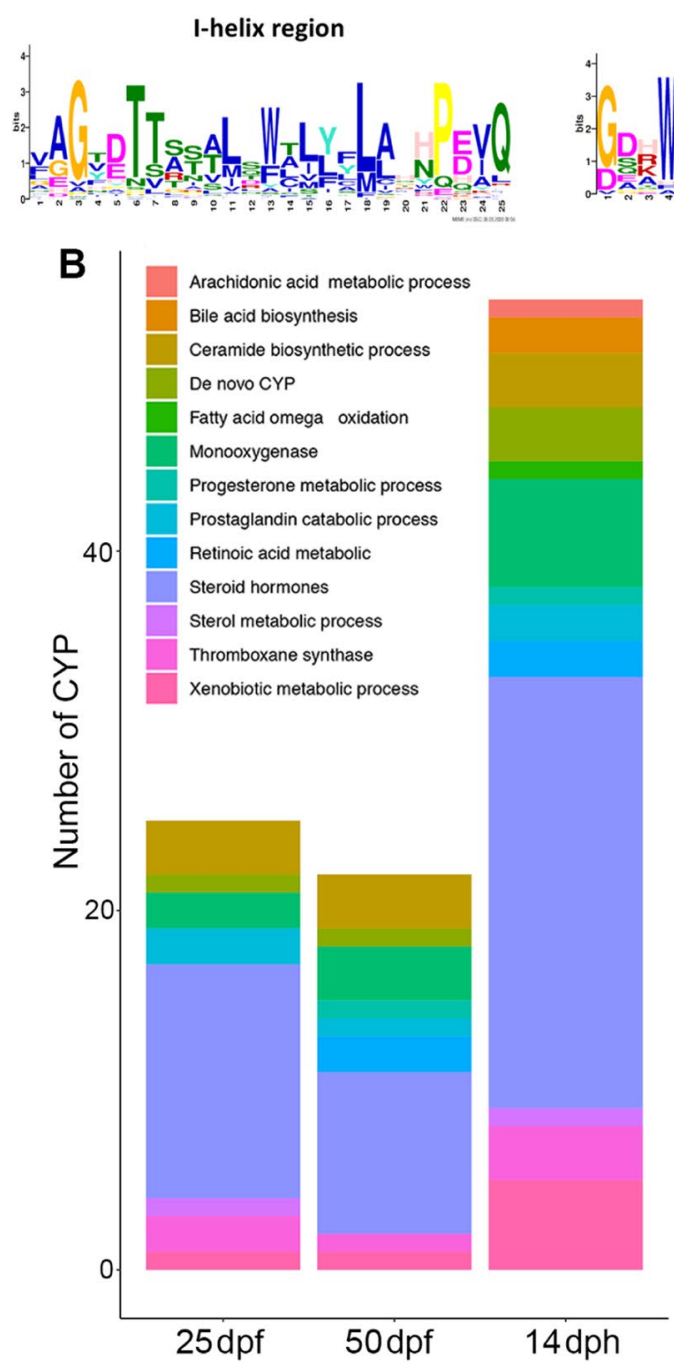

Fig. 7 Summary of cytochrome P450 (CYP450) genes identified in Charonia tritonis and their functional classification. A Sequence logo representation showing conservation within CYP450 regions and motif. B CYP450 at different stages of early life development:

Various classes of CYP450 are dispersed in all adult $C$. tritonis tissues examined, with the highest representation being within the steroid hormone biosynthesis family. The gill presented with the highest number of CYP450 genes (Fig. 7C). The snail's gill is a critical organ for biochemical exchanges with their environment, from gas exchange to filtration of particles and chemicals, including toxins. In fish, there is strong evidence pointing to a major role for gill-associated CYP450s in response to environmental
C-helix region
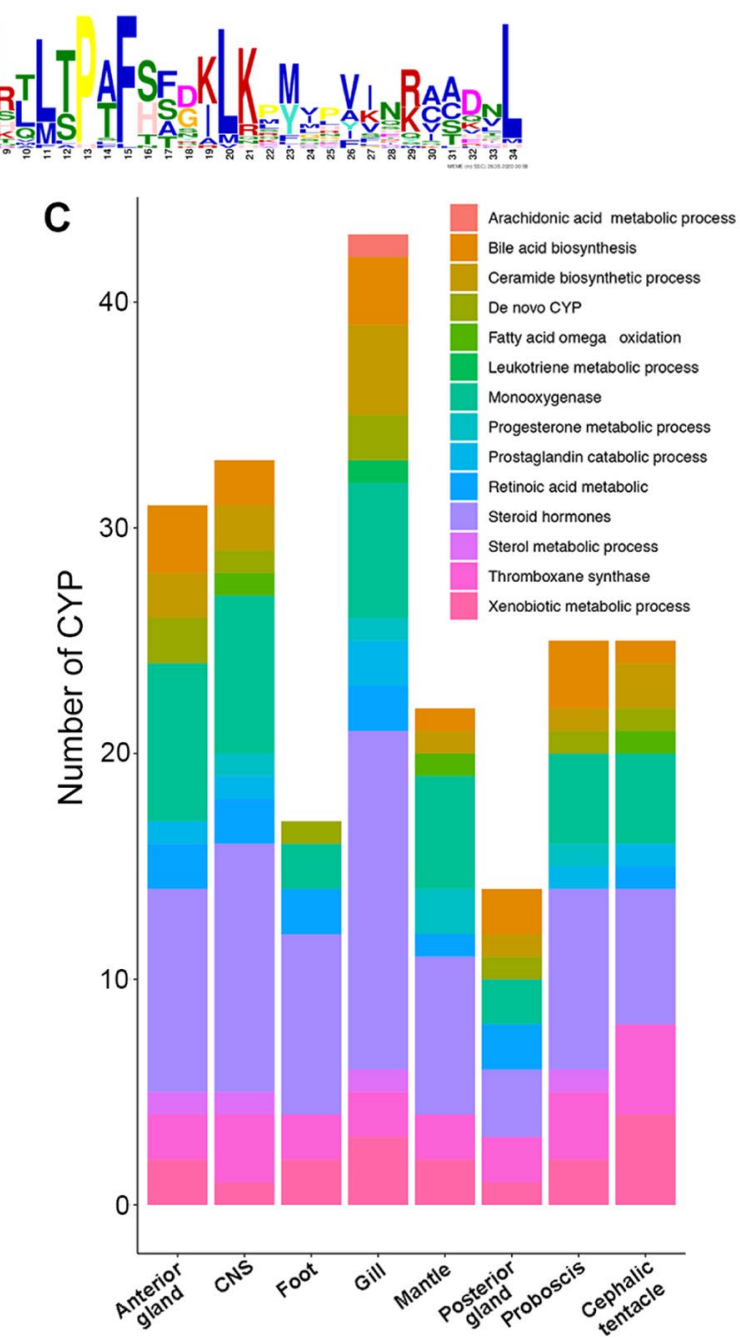

25 days post-fertilisation (dpf), $50 \mathrm{dpf}$ and 14 days post-hatch (dph). C CYP450 within different adult tissues. See Supplementary File S3 for all Charonia tritonis CYP450 sequences

stresses including water pollution (Uno et al. 2012). In molluscs, less is known, however, certain gill-associated CYP450s are differentially expressed in response to the diarrhetic shellfish poison okadaic acid (Chi et al. 2018). Unfortunately, our transcriptomes did not include gonad or digestive tissues (e.g. stomach, hepatopancreas), both of which would be considered key tissues for CYP450 activity during reproductive and detoxification events, respectively. 


\section{Conclusions}

C. tritonis is a threatened species which makes sampling difficult; therefore, the NGS-derived data we have obtained provides an important resource for molecularassociated discoveries that could help overcome bottlenecks in the establishment of aquaculture methods and a breeding program. Our reference $C$. tritonis transcriptome contains 613,506 contigs encoding 61,611 proteins with high confidence, of which 14,095 are fully annotated. We report 143 GPCRs, 53 being designated candidate ORs based on their expression in the cephalic tentacles. Many include rhodopsin-like GPCRs that are known to have chemosensory functions in other species. During development, GPCRs exclusive to veligers have been earmarked as being of particular interest for further characterization, since they could play an important role in detection of settlement cues leading to metamorphosis.

This study also provides a more comprehensive analysis of the $C$. tritonis neuropeptidome, leading to the identification of 117 NPP transcripts. Although much is still to be learnt about the function of NPs derived from these precursors, their identification enables more targeted functional experiments in the future. As a prelude to this, we tested some NPs on veligers and observed a significant increase in veliger heart rate with FFamide. We report 91 CYP450 transcripts, of which their presence was more prominent at post-hatch, likely an essential requirement for survival outside of the egg capsule. Similarly, in adults CYP450 abundance in the gill is more pronounced which may reflect its function in detoxification.

Supplementary Information The online version contains supplementary material available at https://doi.org/10.1007/s10126-021-10042-7.

Acknowledgements This research project has been financially supported by the Australian Federal Government Department of the Environment and Energy Reef 2050 Sustainability Plan Grant ID: 3600000775. We thank Cairns Marine and Pacific Marine Group (PMG) for the collection of adult Charonia tritonis for larval rearing under permits G13/36390.1 and G17/38293.1. Husbandry and maintenance of Charonia tritonis broodstock and larvae would not have been possible without the assistance of the SeaSIM team at AIMS, and PMG for providing Crown-of-Thorns Starfish (COTS). We acknowledge the $\mathrm{PhD}$ scholarship funding from Reef 2050 program (3600000775) to A. Klein, and the Australian Research Council Discovery Project (DP180103694) funding to S. Cummins. The project also benefitted greatly from the efforts of Andres Martin Diaz (larval settlement) and Simon Schnebert (adult husbandry).

\section{Declarations}

Conflict of Interest The authors declare no competing interests.
Open Access This article is licensed under a Creative Commons Attribution 4.0 International License, which permits use, sharing, adaptation, distribution and reproduction in any medium or format, as long as you give appropriate credit to the original author(s) and the source, provide a link to the Creative Commons licence, and indicate if changes were made. The images or other third party material in this article are included in the article's Creative Commons licence, unless indicated otherwise in a credit line to the material. If material is not included in the article's Creative Commons licence and your intended use is not permitted by statutory regulation or exceeds the permitted use, you will need to obtain permission directly from the copyright holder. To view a copy of this licence, visit http://creativecommons.org/licenses/by/4.0/.

\section{References}

Abrams PA (1995) Implications of dynamically variable traits for identifying, classifying, and measuring direct and indirect effects in ecological communities. Am Nat 146:112-134

Adamson KJ, Wang T, Zhao M, Bell F, Kuballa AV, Storey KB, Cummins SF (2015) Molecular insights into land snail neuropeptides through transcriptome and comparative gene analysis. BMC Genomics 16:308

Adema CM, Hillier LW, Jones CS, Loker ES, Knight M, Minx P, Oliveira G, Raghavan N, Shedlock A, Do Amaral LR (2017) Whole genome analysis of a schistosomiasis-transmitting freshwater snail. Nat Commun 8:15451

Antonova Y, Arik AJ, Moore W, Riehle MA, Brown MR (2012) Insulinlike peptides: structure, signaling, and function. Elsevier, Insect endocrinology

Attwood T, Findlay J (1994) Fingerprinting G-protein-coupled receptors. Protein Eng Des Sel 7:195-203

Bai H, Zhu F, Shah K, Palli SR (2011) Large-scale RNAi screen of G protein-coupled receptors involved in larval growth, molting and metamorphosis in the red flour beetle. BMC Genomics 12:388

Bailey TL, Boden M, Buske FA, Frith M, Grant CE, Clementi L, Ren J, Li WW, Noble WS (2009) MEME SUITE: tools for motif discovery and searching. Nucleic Acids Res 37:W202-W208

Bankers L, Fields P, Mcelroy KE, Boore JL, Logsdon JM Jr, Neiman M (2017) Genomic evidence for population-specific responses to co-evolving parasites in a New Zealand freshwater snail. Mol Ecol 26:3663-3675

Berg C (1971) Egg capsule and early veliger of Charonia tritonis. Veliger 13:298

Bernot RJ, Turner AM (2001) Predator identity and trait-mediated indirect effects in a littoral food web. Oecologia 129:139-146

Bolger AM, Lohse M, Usadel B (2014) Trimmomatic: a flexible trimmer for Illumina sequence data. Bioinformatics 30:2114-2120

Bolnick DI, Preisser EL (2005) Resource competition modifies the strength of trait-mediated predator-prey interactions: A metaanalysis. Ecology 86:2771-2779

Bose U, Suwansa-Ard S, Maikaeo L, Motti C, Hall M, Cummins S (2017a) Neuropeptides encoded within a neural transcriptome of the giant triton snail Charonia tritonis, a Crown-of-Thorns Starfish predator. Peptides 98:3-14

Bose U, Wang T, Zhao M, Motti C, Hall M, Cummins S (2017b) Multiomics analysis of the giant triton snail salivary gland, a crownof-thorns starfish predator. Sci Rep 7:6000

Braubach OR, Dickinson AJ, Evans CC, Croll RP (2006) Neural control of the velum in larvae of the gastropod, Ilyanassa obsoleta. J Exp Biol 209:4676-4689

Brown J, Pirrung M, Mccue LA (2017) FQC Dashboard: integrates FastQC results into a web-based, interactive, and extensible FASTQ quality control tool. Bioinformatics 33:3137-3139 
Brown KM, \& Alexander Jr JE (1994) Group foraging in a marine gastropod predator: benefits and costs to individuals. Mar Ecol Prog Ser 97-105

Buckett K, Peters M, Dockray G, Van Minnen J, Benjamin P (1990) Regulation of heartbeat in Lymnaea by motoneurons containing FMRFamide-like peptides. J Neurophysiol 63:1426-1435

Cahill AE, \& Koury SA (2016) Larval settlement and metamorphosis in a marine gastropod in response to multiple conspecific cues. PeerJ 4: e2295

Cartmell J, Schoepp DD (2000) Regulation of neurotransmitter release by metabotropic glutamate receptors. J Neurochem 75:889-907

Chen M, Walker R (1992) Actions of APGW-amide and GW-amide on identified central neurons of the snail, Helix aspersa. Comparative Biochemistry and Physiology Part C: Comp Pharmacology 102:509-516

Chi C, Giri SS, Jun JW, Kim SW, Kim HJ, Kang JW, Park SC (2018) Detoxification-and immune-related transcriptomic analysis of gills from bay scallops (Argopecten irradians) in response to algal toxin okadaic acid. Toxins 10:308

Cochilla AJ, Alford S (1998) Metabotropic glutamate receptor-mediated control of neurotransmitter release. Neuron 20:1007-1016

Conesa A, Götz S, García-Gómez JM, Terol J, Talón M, Robles M (2005) Blast2GO: a universal tool for annotation, visualization and analysis in functional genomics research. Bioinformatics 21:3674-3676

Conzelmann M, Offenburger S-L, Asadulina A, Keller T, Münch TA, Jékelya G (2011) Neuropeptides regulate swimming depth of Platynereis larvae. Proc Natl Acad Sci 108:e1174-1183

Conzelmann M, Williams E, Krug K, Franz-Wachtel M, Macek BJ, ' kely, G. (2013) The neuropeptide complement of the marine annelid Platynereis dumerilii. BMC Genomics 14:906

Couper JM, Leise EM (1996) Serotonin injections induce metamorphosis in larvae of the gastropod mollusc Ilyanassa obsoleta. Biol Bull 191:178-186

Croll R, Van Minnen J, Kits K, \& Smit A (1991) APGWamide: Molecular, histological and physiological examination of a novel neuropeptide involved with reproduction in the snail, Lymnaea stagnalis. Molluscan neurobiology 248-254

Croll RP, Van Minnen J (1992) Distribution of the peptide Ala-Pro-GlyTrp-NH2 (APGWamide) in the nervous system and periphery of the snail Lymnaea stagnalis as revealed by immunocytochemistry and in situ hybridization. J Comp Neurol 324:567-574

Crooks GE, Hon G, Chandonia J-M, Brenner SE (2004) WebLogo: a sequence logo generator. Genome Res 14:1188-1190

Cropper EC, Miller MW, Tenenbaum R, Kolks MAG, Kupfermann I, Weiss KR (1988) Structure and action of buccalin: A modulatory neuropeptide localized to an identified small cardioactive peptide-containing cholinergic motor neuron of Aplysia californica. Proc Natl Acad Sci 85:6177-6181

Cummins SF, Erpenbeck D, Zou Z, Claudianos C, Moroz LL, Nagle GT, Degnan BM (2009) Candidate chemoreceptor subfamilies differentially expressed in the chemosensory organs of the mollusc Aplysia. BMC Biol 7:28

Cummins SF, Nuurai P, Nagle GT, Degnan BM (2010) Conservation of the egg-laying hormone neuropeptide and attractin pheromone in the spotted sea hare, Aplysia dactylomela. Peptides 31:394-401

Davenport AP, Alexander SP, Sharman JL, Pawson AJ, Benson HE, Monaghan AE, Liew WC, Mpamhanga CP, Bonner TI, Neubig RR (2013) International Union of Basic and Clinical Pharmacology. LXXXVIII. G protein-coupled receptor list: recommendations for new pairings with cognate ligands. Pharmacol Rev 65:967-986

De Lange R, Van Golen F, Van Minnen J (1997) Diversity in cell specific co-expression of four neuropeptide genes involved in control of male copulation behaviour in Lymnaea stagnalis. Neuroscience 78:289-299
De Oliveira A, Wollesen T, Kristof A, Scherholz M, Redl E, Todt C, Bleidorn C, Wanninger A (2016) Comparative transcriptomics enlarges the toolkit of known developmental genes in mollusks. BMC Genomics 17:905

Dickinson A, Croll RP, Voronezhskaya EE (2000) Development of embryonic cells containing serotonin, catecholamines, and FMRFamide-related peptides in Aplysia californica. Biol Bull 199:305-315

Dickinson AJ, Croll RP (2001) Neurocalcin-like immunoreactivity in embryonic stages of the gastropod molluscs Aplysia californica and Lymnaea stagnalis. Invertebr Biol 120:206-216

Dill LM, Heithaus MR, Walters CJ (2003) Behaviorally mediated indirect interactions in marine communities and their conservation implications. Ecology 84:1151-1157

Endean R (1969) Report on investigations made into aspects of the current Acanthaster planci (crown-of-thorns) infestations of certain reefs of the Great Barrier Reef: Fisheries Branch

Fernandes D, Loi B, Porte C (2011) Biosynthesis and metabolism of steroids in molluscs. J Steroid Biochem Mol Biol 127:189-195

Finn RD, Bateman A, Clements J, Coggill P, Eberhardt RY, Eddy SR, Heger A, Hetherington K, Holm L, Mistry J (2013) Pfam: the protein families database. Nucleic Acids Res 42:D222-D230

Finn RD, Clements J, Eddy SR (2011) HMMER web server: interactive sequence similarity searching. Nucleic Acids Res 39:W29-W37

Freeman KA (2001) Aquaculture and related biological attributes of abalone species in Australia. A review

Geraerts W, Smit A, Li K, Vreugdenhil E, Van Heerikhuizen H (1991) Neuropeptide gene families that control reproductive behaviour and growth in molluscs. Springer, Current Aspects of the Neurosciences

Gerdol M, Fujii Y, Hasan I, Koike T, Shimojo S, Spazzali F, Yamamoto K, Ozeki Y, Pallavicini A, Fujita H (2017) The purplish bifurcate mussel Mytilisepta virgata gene expression atlas reveals a remarkable tissue functional specialization. BMC Genomics 18:590

Grabherr MG, Haas BJ, Yassour M, Levin JZ, Thompson DA, Amit I, Adiconis X, Fan L, Raychowdhury R, Zeng Q (2011) Trinity: reconstructing a full-length transcriptome without a genome from RNA-Seq data. Nat Biotechnol 29:644

Hadfield MG (1984) Settlement requirements of molluscan larvae: new data on chemical and genetic roles. Aquaculture 39:283-298

Hall A, Kingsford M (2016) Variation in the population demographics of Scolopsis bilineatus in response to predators. Coral Reefs 35:1173-1185

Hall JD, Lloyd PE (1990) Involvement of pedal peptide in locomotion in Aplysia: modulation of foot muscle contractions. J Neurobiol 21:858-868

Hall M, Motti C, \& Kroon F (2017a) The potential role of the giant triton snail, Charonia tritonis (Gastropoda: Ranellidae) in mitigating populations of the crown-of-thorns starfish. Reef and Rainforest Research Centre Limited, Cairns

Hall MR, Kocot KM, Baughman KW, Fernandez-Valverde SL, Gauthier ME, Hatleberg WL, Krishnan A, Mcdougall C, Motti CA, Shoguchi $\mathrm{E}$ (2017b) The crown-of-thorns starfish genome as a guide for biocontrol of this coral reef pest. Nature 544:231

Hannemann F, Bichet A, Ewen KM, \& Bernhardt R (2007) Cytochrome P450 systems - biological variations of electron transport chains. Biochimica et Biophysica Acta (BBA)-General Subjects 1770: 330-344

Heyland A, Vue Z, Voolstra CR, Medina M, Moroz LL (2011) Developmental transcriptome of Aplysia californica'. J Exp Zool B Mol Dev Evol 316:113-134

Hu GM, Secario M, \& Chen CM (2019) SeQuery: an interactive graph database for visualizing the GPCR superfamily. Database, 2019

Ip JC, Leung PT, Ho KK, Qiu J, Leung KM (2016) De novo transcriptome assembly of the marine gastropod Reishia clavigera for supporting toxic mechanism studies. Aquat Toxicol 178:39-48 
Ip JC, Mu H, Chen Q, Sun J, Ituarte S, Heras H, Van Bocxlaer B, Ganmanee M, Huang X, Qiu J-W (2018) AmpuBase: a transcriptome database for eight species of apple snails (Gastropoda: Ampullariidae). BMC Genomics 19:179

Isin EM, \& Guengerich FP (2007) Complex reactions catalyzed by cytochrome P450 enzymes. Biochimica et Biophysica Acta (BBA)-General Subjects 1770: 314-329

Jia K, Albert PS, Riddle DL (2002) DAF-9, a cytochrome P450 regulating $\mathrm{C}$. elegans larval development and adult longevity. Development 129:221-231

Kamyab E, Kellermann MY, Kunzmann A, \& Schupp PJ (2019) Chemical Biodiversity and Bioactivities of Saponins in Echinodermata with an Emphasis on Sea Cucumbers (Holothuroidea). YOUMARES 9-The Oceans: Our Research, Our Future: 121

Kellett E, Perry SJ, Santama N, Worster BM, Benjamin PR, Burke JF (1996) Myomodulin gene of Lymnaea: structure, expression, and analysis of neuropeptides. J Neurosci 16:4949-4957

Klein AH, Ballard KR, Storey KB, Motti CA, Zhao M, \& Cummins SF (2019) Multi-omics investigations within the Phylum Mollusca, Class Gastropoda: from ecological application to breakthrough phylogenomic studies. Briefings in Functional Genomics, in press

Kolakowski JL (1994) GCRDb: a G-protein-coupled receptor database. Receptors Channels 2:1-7

Kuroki Y, Kanda T, Kubota I, Fujisawa Y, Ikeda T, Miura A, Minamitake Y, Muneoka Y (1990) A molluscan neuropeptide related to the crustacean hormone, RPCH. Biochem Biophys Res Commun 167:273-279

Langmead B, Trapnell C, Pop M, Salzberg SL (2009) Ultrafast and memory-efficient alignment of short DNA sequences to the human genome. Genome Biol 10:R25

Li KW, El Filali Z, Van Golen FA, Geraerts WP (1995) Identification of a Novel Amide Peptide, GLTPNMNSLFF-NH2, Involved in the Control of Vas Deferens Motility in Lymnaea stagnalis. Eur J Biochem 229:70-72

Liu C, Zhang Y, Ren Y, Wang H, Li S, Jiang F, Yin L, Qiao X, Zhang G, \& Qian W (2018) The genome of the golden apple snail Pomacea canaliculata provides insight into stress tolerance and invasive adaptation. GigaScience 7: giy 101

Liu G, Santos D, Takeuchi H (1993) Sensitivities of Achatina giant neurones to peptides isolated from mollusca. Acta Biol Hung $44: 25-28$

Liu GJ, Santos DE, Takeuchi H, Kamatani Y, Minakata H, Nomoto K, Kubota I, Ikeda T, Muneoka Y (1991) APGW-amide as an inhibitory neurotransmitter of Achatina fulica Ferussac. Biochem Biophys Res Commun 177:27-33

Liu GJ, Takeuchi H (1993) Modulation of neuropeptide effects by achatin-I, an Achatina endogenous tetrapeptide. Eur J Pharmacol 240:139-145

Liu GJ, Takeuchi H (1995) Suppressing effects of neuroactive peptides on the inward current caused by achatin-I, an Achatina endogenous peptide. General Pharmacology: the Vascular System 26:765-772

Luttbeg B, Kerby JL (2005) Are scared prey as good as dead? Trends Ecol Evol 20:416-418

Mansuy D (1998) The great diversity of reactions catalyzed by cytochromes P450. Comp Biochem Physiol C: Pharmacol Toxicol Endocrinol 121:5

Mirabeau O, Joly JS (2013) Molecular evolution of peptidergic signaling systems in bilaterians. Proc Natl Acad Sci 110:E2028-E2037

Mittal B, Tulsyan S, Kumar S, Mittal RD, \& Agarwal G (2015) Cytochrome P450 in cancer susceptibility and treatment. Advances in clinical chemistry. Elsevier

Moon JS, Choi YH (2020) Role of the insulin-like growth factor system in gonad sexual maturation in Pacific oyster Crassostrea gigas. Fisheries and Aquatic Sciences 23:1-8
Morgan SG, Gravem SA, Lipus AC, Grabiel M, Miner BG (2016) Trait-mediated indirect interactions among residents of rocky shore tidepools. Mar Ecol Prog Ser 552:31-46

Morishita F (2017) Neuropeptides and Their Physiological Functions in Mollusks. Springer, Biological Effects by Organotins

Motti CA, Bose U, Roberts RE, Mcdougall C, Smith MK, Hall MR, Cummins SF (2018) Chemical ecology of chemosensation in Asteroidea: insights towards management strategies of pest species. J Chem Ecol 44:147-177

Mu H, Sun J, Heras H, Chu KH, Qiu J-W (2017) An integrated proteomic and transcriptomic analysis of perivitelline fluid proteins in a freshwater gastropod laying aerial eggs. J Proteomics 155:22-30

Nateewathana A, Aungtonya C (1994) The Indo Pacific trumpet triton snail, Charonia tritonis: Morphometrics of a species on the verge of local extinction. Phuket Marine Biological Center Special Publication 13:137-140

Nelson DR (2009) The cytochrome p450 homepage. Hum Genomics 4:59

Nugranad J, Promjinda K, Varapibal T, Chantara S (2001) Reproduction of the trumpet triton Charonia tritonis (Mollusca; Gastropoda) in captivity. Phuket Marine Biological Center Special Publication 25:153-160

Paterson JC, Poulsen AL (1988) A study of Charonia tritonis on the Great Barrier Reef. Report to the Great Barrier Reef Marine Park Authority, DOI

Paterson RA, Pritchard DW, Dick JT, Alexander ME, Hatcher MJ, Dunn AM (2013) Predator cue studies reveal strong trait-mediated effects in communities despite variation in experimental designs. Anim Behav 86:1301-1313

Peckarsky BL, Abrams PA, Bolnick DI, Dill LM, Grabowski JH, Luttbeg B, Orrock JL, Peacor SD, Preisser EL, Schmitz OJ (2008a) Revisiting the classics: considering nonconsumptive effects in textbook examples of predator-prey interactions. Ecology 89:2416-2425

Peckarsky BL, Kerans BL, Taylor BW, Mcintosh AR (2008b) Predator effects on prey population dynamics in open systems. Oecologia 156:431-440

Penniman JR, Doll MK, Pires A (2013) Neural correlates of settlement in veliger larvae of the gastropod, Crepidula fornicata. Invertebr Biol 132:14-26

Pinnegar J, Polunin N, Francour P, Badalamenti F, Chemello R, HarmelinVivien ML, Hereu B, Milazzo M, Zabala M, D'anna G (2000) Trophic cascades in benthic marine ecosystems: lessons for fisheries and protected-area management. Environ Conserv 27:179-200

Preisser EL, \& Bolnick DI (2008) The many faces of fear: comparing the pathways and impacts of nonconsumptive predator effects on prey populations. PloS One 3: e2465

Preisser EL, Bolnick DI, Benard MF (2005) Scared to death? The effects of intimidation and consumption in predator-prey interactions. Ecology 86:501-509

Price DA, Greenberg MJ (1977) Structure of a molluscan cardioexcitatory neuropeptide. Science 197:670-671

Rewitz KF, Styrishave B, Løbner-Olesen A, Andersen O (2006) Marine invertebrate cytochrome P450: emerging insights from vertebrate and insect analogies. Comp Biochem Physiol C Toxicol Pharmacol 143:363-381

Scheltema R, \& Rs S (1974) Biological interactions determining larval settlement of marine invertebrates

Schmitz OJ, Beckerman AP, O’brien KM (1997) Behaviorally mediated trophic cascades: effects of predation risk on food web interactions. Ecology 78:1388-1399

Simão FA, Waterhouse RM, Ioannidis P, Kriventseva EV, Zdobnov EM (2015) BUSCO: assessing genome assembly and annotation completeness with single-copy orthologs. Bioinformatics $31: 3210-3212$ 
Song H, Yu ZL, Sun LN, Xue DX, Zhang T, Wang HY (2016) Transcriptomic analysis of differentially expressed genes during larval development of Rapana venosa by digital gene expression profiling. G3 (Bethesda) 6:2181-2193

Stewart MJ, Favrel P, Rotgans BA, Wang T, Zhao M, Sohail M, O'connor, W.A., Elizur, A., Henry, J. \& Cummins, S.F. (2014) Neuropeptides encoded by the genomes of the Akoya pearl oyster Pinctata fucata and Pacific oyster Crassostrea gigas: a bioinformatic and peptidomic survey. BMC Genomics 15:840

Stewart MJ, Wang T, Harding BI, Bose U, Wyeth RC, Storey KB, Cummins SF (2016) Characterisation of Reproduction-Associated Genes and Peptides in the Pest Land Snail. Theba Pisana Plos One 11:e0162355

Sun J, Wang M, Wang H, Zhang H, Zhang X, Thiyagarajan V, Qian P, Qiu J (2012) De novo assembly of the transcriptome of an invasive snail and its multiple ecological applications. Mol Ecol Resour 12:1133-1144

Thorson G (1950) Reproductive and larval ecology of marine bottom invertebrates. Biol Rev 25:1-45

Toscano BJ, Griffen BD (2014) Trait-mediated functional responses: predator behavioural type mediates prey consumption. J Anim Ecol 83:1469-1477

Uno T, Ishizuka M, Itakura T (2012) Cytochrome P450 (CYP) in fish. Environ Toxicol Pharmacol 34:1-13

Van Golen F, Li K, De R, Van Kesteren R, Van Der Schors R, Geraerts W (1995) Co-localized neuropeptides conopressin and ALAPRO-GLY-TRP-NH2 have antagonistic effects on the vas deferens of Lymnaea. Neuroscience 69:1275-1287

Van Kesteren R, Smit A, De Lange R, Kits K, Van Golen F, Van Der Schors R, Burke J, Geraerts W (1995) Structural and functional evolution of the vasopressin/oxytocin superfamily: vasopressinrelated conopressin is the only member present in Lymnaea, and is involved in the control of sexual behavior. J Neurosci 15:5989-5998

Veenstra JA (2010) Neurohormones and neuropeptides encoded by the genome of Lottia gigantea, with reference to other mollusks and insects. Gen Comp Endocrinol 167:86-103

Wang Q, Hong X, Chen H, Yuan L, Zha J (2018) The neuropeptides of Asian freshwater clam (Corbicula fluminea) as new molecular biomarker basing on the responses of organophosphate chemicals exposure. Ecotoxicol Environ Saf 160:52-59

Witman JD, Genovese SJ, Bruno JF, Mclaughlin JW, Pavlin BI (2003) Massive prey recruitment and the control of rocky subtidal communities on large spatial scales. Ecol Monogr 73:441-462

Yang JL, Li WS, Liang X, Li YF, Chen YR, Bao WY, Li JL (2014) Effects of adrenoceptor compounds on larval metamorphosis of the mussel Mytilus coruscus. Aquaculture 426:282-287

York PS, Cummins SF, Degnan SM, Woodcroft BJ, Degnan BM (2012) Marked changes in neuropeptide expression accompany broadcast spawnings in the gastropod Haliotis asinina. Front Zool 9:9

Zhang H, He M (2020) The role of a new insulin-like peptide in the pearl oyster Pinctada fucata martensii. Sci Rep 10:1-12

Zhang LP, Xia JJ, Peng PF, Li HP, Luo P, Hu CQ (2013) Characterization of embryogenesis and early larval development in the Pacific triton, Charonia tritonis (Gastropoda: Caenogastropoda). Invertebr Reprod Dev 57:237-246

Zhao M, Wang T, Adamson K, Storey K, Cummins S (2016) Multitissue transcriptomics for construction of a comprehensive gene resource for the terrestrial snail Theba pisana. Sci Rep 6:20685

Publisher's Note Springer Nature remains neutral with regard to jurisdictional claims in published maps and institutional affiliations. 